\title{
IMPLEMENTASI KEBIJAKAN PERLINDUNGAN PEKERJA DI BAWAH UMUR DI DINAS SOSIAL KOTA MAKASSAR
}

\author{
Kartini $^{1}$, Jaelan Usman ${ }^{2}$, Nuryanti Mustari ${ }^{3}$ \\ 1). Mahasiswa Ilmu Administrasi Negara Fisipol Unismuh Makassar \\ 2). Dosen Ilmu Administrasi Negara Fisipol Unismuh Makassar \\ 3). Dosen Ilmu Administrasi Negara Fisipol Unismuh Makassar
}

\begin{abstract}
This research is to describe and explain a Worker Protection Policy Implementation At Underage In Social National Education In Makassar City. The kind of research which be used, is qualitative descriptive. The data that is collected by observation, interview, and documentation based on the result of research, it can be known about a Worker Protection Policy Implementation Of Underage In Social National Education In Makassar City involves the policy of the children protection underage namely respect and guarantee the rights of children, give the encouragement of infrastructure, the treatment of parents of children, and human power resources quality, and then obstacle factor is the lack an infrastructure, a retardation funds, and the mastering in technology are less good.
\end{abstract}

Keywords:Policy Implementation, Worker Protection.

\begin{abstract}
ABSTRAK
Penelitian ini menggambarkan dan menjelaskan tentang Implementasi Kebijakan Perlindungan Pekerja di Bawah umur di Dinas sosial kota Makassar. Jenis penelitian yang digunakan adalah deskriptif kualitatif. Data dikumpulkan melalui observasi, wawancara, dan dokumentasi. Berdasarkan hasil penelitian maka dapat diketahui mengenai Implementasi Kebijakan Perlindungan Pekerja di Bawah Umur di Dinas Sosial kota Makassar meliputi Kebijakan Perlindungan Anak di bawah Umur yaitu Menghormati dan menjamin hak anak, Memberikan dukungan sarana dan prasarana, Perlakuan Orang Tua Terhadap Anak, dan Anak menggunakan hak sesuai usia dan kecerdasannya. Adapun faktor pendukung yaitu Kualitas Sumber Daya Manusia, kemudian faktor penghambat yaitu Kurangnya sarana dan prasarana, Keterbatasan dana,dan Penguasaaan terhadap tekhnologi yang kurang baik.
\end{abstract}

kata kunci: Implementasi Kebijakan, Perlindungan Pekerja.

Website : http://journal.unismuh.ac.id/index.php/kolaborasi 


\section{PENDAHULUAN}

Anak merupakan harta yang tidak ternilai harganya, tidak saja dilihat dalam perspektif sosial, budaya, ekonomi, politik, hukum, tetapi juga dalam perspektif keberlanjutan sebuah generasi keluarga, suku, ras, maupun bangsa. Mengingat pentingnya status dan posisi anak tersebut Purnianti dan Martini (2002:5) berpendapat bahwa anak dapat bermakna sosial (kehormatan harkat martabat keluarga tergantung pada sikap dan perilaku anak), budaya(anak merupakan harta dan kekayaan sekaligus merupakan lambang kesuburan sebuah keluarga), politik (anak adalah penerus trah atau suku masyarakat tertentu), ekonomi (pada sementara anggapan masyarakat Jawa khususnya ada adagium 'banyak anak banyak rejeki, sehingga 'mengkaryakan' atau memperkerjakan anak dapat menambah penghasilan atau rejeki), hukum(anak mempunyai posisi dan kedudukan strategis didepan hukum).

Potensi angka putus sekolah akibat krisis, berdasarkan perkiraan
Bappenas meningkat tajam, dari 2,8 juta menjadi 8 juta pertahun (Haryadi, 1995: 22). Dan yang memprihatinkan, bersamaan dengan makin tingginya kecenderungan anak putus sekolah, adalah kemungkinan bertambahnya anak-anak usia sekolah yang terpaksa bekerja untuk membantu ekonomi keluarga. Walaupun ada seperangkat peraturan yang melindungi pekerja anak, tetapi kecenderungan kualitas permasalahan pekerja anak dari tahun ke tahun mengalami perkembangan kompleksitas menuju bentuk-bentuk pekerjaan terburuk yang eksploitatif dan membahayakan pertumbuhan dan perkembangan fisik, mental, moral, sosial dan intelektual anak.Jenis pekerjaan terburuk semakin marak ditemukan, seperti anak yang dilancarkan, anak yang diperdagangkan, anak bekerja di pertambangan, anak jernal dan lainlain. Pada tahun 1990-an mulai muncul isu anak jalanan (anjal), anak jermal, anak yang bekerja di perkebunan. Pada tahun 1996 muncul isu pelacuran anak, anak yang bekerja di pertambangan, 
nelayan.Sedangkan pada tahun 1998 muncul isu perdagangan anak (Child trafficking) untuk dilacurkan, pembantu rumah tangga anak dan bentuk-bentuk terburuk pekerjaan anak lainnya (Wiryani, 2003: 3).

Terjadinya pekerja anak dipengaruhi oleh berbagai faktor sosial seperti kemiskinan, urbanisasi, sosial budaya, pendidikan, perubahan proses produksi serta lemahnya pengawasan dan minimnya lembaga untuk rehabilitasi. Namun pada kenyataannya keterlibatan anak dalam pekerjaan mayoritas didorong oleh faktor kemiskinan atau ekonomi. Untuk dapat mendalami proses implementasi maka perlu dipahami konsep implementasi terlebih dahulu. Penggunaan istilah implementasi mulai muncul ke permukaan beberapa dekade yang lalu.Yang pertama menggunakan istilah tersebut adalah Laswell dalam Purwanto (2012:17). Sebagai ilmuan yang pertama kali mengembangkan studi tentang kebijakan publik, Laswell menggagas suatu pendekatan yang ia sebut sebagai pendekatan proses. Menurutnya, agar ilmuan dapat memperoleh pemahaman yang baik tentang apa sesungguhnya kebijakan publik, maka kebijakan publik tersebut harus diurai menjadi beberapa bagian sebagai tahapantahapan, yaitu: agenda setting, formulasi, legitimasi, implementasi, evaluasi, reformulasi, dan terminasi. Dari siklus kebijakan tersebut terlihat secara jelas bahwa implementasi hanyalah bagian atau salah satu tahap dari proses besar bagaimana suatu kebijakan publik dirumuskan.

Hakikat utama implementasi kebijakan adalah memahami apa yang seharusnya terjadi sesudah suatu program dinyatakan berlaku atau dirumuskan. Pemahaman tersebut mencakup usaha-usaha untuk mengadministrasikannya dan menimbulkan dampak nyata pada masyarakat atau kejadian-kejadian (Mazmanian dan Sabatier dalam Widodo (2010:87)).Faktor-faktor yang mempengaruhi keberhasilan atau kegagalan implementasi kebijakan yaitu faktor communication, resources, 
disposition, dan bureaucratic structure (Edward dalam. Widodo, 2011:96-1 $10)$.

Agustino (2006:155) menerang kan bahwa implementasi kebijakan dikenal dua pendekatan yaitu:"Pendekatan top down yang serupa dengan pendekatan command and control (Lester Stewart, 2000:108) dan pendekatan bottom up yang serupa dengan pendekatan the market approach (Lester Stewart, 2000:108). Pendekatan top down atau command and control dilakukan secara tersentralisasi dimulai dari aktor ditingkat pusat dan keputusankeputusan diambil ditingkat pusat. Pendekatan top down bertolak dari perspektif bahwa keputusan-keputusan politik (kebijakan) yang telah ditetapkan oleh pembuat kebijakan harus dilaksanakan oleh Administratur atau birokrat yang berada pada level bawah (street level bureaucrat)".

Bertolak belakang dengan pendekatan top down, pendekatan bottom up lebih menyoroti implementasi kebijakan yang terformulasi dari inisiasi warga masyarakat. Argumentasi yang diberikan adalah masalah dan persoalan yang terjadi pada level daerah hanya dapat dimengerti secara baik oleh warga setempat. Sehingga pada tahap implementasinya pun suatu kebijakanselalu melibatkan masyarakat secara partisipatif. Program dalam konteks implementasi kebijakan publik terdiri dari beberapa tahap yaitu: (1) Merancang bangun (design) program beserta perincian tugas dan perumusan tujuan yang jelas, penentuan ukuran prestasi yang jelas serta biaya dan waktu; (2) Melaksanakan (aplicatiori) program dengan mendayagunakan struktur-struktur dan personalia, dana serta sumber-sumber lainnya, prosedur dan metode yang tepat; Membangun sistem penjadwalan, monitoring dan sarana-sarana pengawasan yang tepat guna serta evaluasi (hasil) pelaksanaan kebijakan (Tachjan, 2006:35). Tachjan (2006:35) mendefinisikan bahwa: "target group yaitu sekelompok orang atau organisasi dalam masyarakat yang 
akan menerima barang atau jasa yang akan dipengaruhi perilakunya oleh kebijakan".

Menurut Pasal 1 Ayat 2 Undang Undang No 23 Tahun 2002 tentang Perlindungan Anak bahwa yang dimaksud perlindungan anak adalah segala kegiatan untuk menjamin dan melindungi anak dan hak-haknya agar dapat hidup, tumbuh, berkembang, dan berpartisipasi, secara optimal sesuai harkat dan martabat kemanusiaan, serta mendapat perlindungan dari kekerasan dan diskriminasi. Dalam Pasal 13 ayat (1) menyatakan bahwa "Setiap anak selama dalam pengasuhan orang tua, wali, atau pihak lain manapun yang bertanggungjawab atas pengasuhan berhak mendapatkan perlindungan dari perlakuan diskriminasi, eksploitasi baik ekonomi maupun seksual, penelantaran, kekejaman, kekerasan, dan penganiayaan, ketidakadilan dan prlakuan salah lainnya". Pasal 59 menyatakan bahwa "Pemerintah dan lembaga negara lainnya berkewajiban dan bertanggungjawab untuk memberikan perlindungan khusus kepada anak dalam situasi darurat, anak yang berhadapan dengan hukum, anak dari kelompok minoritas dan terisolasi, anak yang tereksploitasi secara ekonomi dan/atau seksual, anak yang diperdagangkan, anak yang menjadi korban penyalahgunaan narkotika, alkohol, psikotropika dan zat adiktif lainnya (napza), anak korban penculikan, penjualan dan perdagangan, anak korban kekerasan baik fisik dan/ atau mental, anak yang menyandang cacat dan anak korban perlakuan salah dan penelantaran”.

\section{METODE PENELITIAN}

Waktu penelitian dilaksanakan pada tanggal 06 Juni sampai 06 Agustus 2015 dan lokasi penelitian dipusatkan di tempat pelelangan ikan paotere kota Makassar karena kesesuaian judul penelitian. Dengan pertimbangan bahwa tempat ini menjadi Pusat pekerja anak di kota Makassar.penulis menggunakan metode deskriptif kualitatif, yaitu suatu metode yang didalam 
penulisannya, penulis harus mengetahui, menggambarkan, dan memaparkan sesuatu keadaan yang ada atau yang terjadi di lapangan. Informan merupakan orang-orang yang dapat memberikan informasi yang dibutuhkan selama penelitian berlangsung terkait tentang implementasi Kebijakan perlindungan Pekerja di bawah Umur di Dinas Sosial Kota Makassar, Penentuan Narasumber (informan) dalam penelitian ini untuk diwawancarai secara mendalam dilakukan dengan cara, peneliti memilih orang tertentu yang dipandang memiliki pengetahuan dan informasi mengenai permasalahan yang diteliti yakni pihak-pihak yang terlibat sebagai partisipan dalam implementasi kebijakan publik yakni: (1) Dinas sosial Provinsi Sulsel1 orang; (2) Anak yang mendapat perhatian4 orang; (3) Pengelola Pelelangan Ikan Paotere1 orang; (4) Masyarakat sebanyak 2 orang.

\section{HASIL DAN PEMBAHASAN}

Secara administrasi kota ini terdiri dari 14 kecamatan dan 143 kelurahan. Kota ini berada pada ketinggian antara 0-25 m daripermukaan laut. Penduduk Kota Makassar pada tahun 2000 adalah1.130.384 jiwa yang terdiri dari lakilaki557.050 jiwa dan perempuan 573.334 jiwa dengan pertumbuhanratarata $1,65 \%$. Masyarakat Kota makassar terdiri dari beberapa etnis yang hidup berdampingan secara damai seperti Etnis Bugis, etnis Makassar, etnis Cina, etnis Toraja, etnis Mandar dll. Kota dengan populasi 1.112.688 jiwa ini, mayoritas penduduknya beragama Islam. Dalam sejarah perkembangan Islam, Makassar adalah kota kunci dalam penyebaran agama Islam ke Kalimantan, Philipina Selatan, NTB dan Maluku. Munculnya kasus SARA di Ambon -- Maluku dan Poso pada beberapa tahun terakhir ini, tidak terlepas dari peran strategis Makassar sebagai kota pintu di wilayah Timur Indonesia. Kekristenan di Makassar 
dalam beberapa tahun terakhir ini sering menjadi sasaran serbuan.

Kota Makassar mempunyai posisi strategis karena berada di persimpangan jalur lalu lintas dari arah selatan dan utara dalam propinsi di Sulawesi, dari wilayah kawasan Barat ke wilayah kawasan Timur Indonesia dan dari wilayah utara ke wilayah selatan Indonesia. Dengan kata lain, wilayah kota Makassar berada koordinat 119 derajat bujur timur dan 5,8 derajat lintang selatan dengan ketinggian yang bervariasi antara 1-25 meter dari permukaan laut. Kota Makassar merupakan daerah pantai yang datar dengan kemiringan $0-5$ derajat ke arah barat, diapit dua muara sungai yakni sungai.Tallo yang bermuara di bagian utara kota dan sungai Jeneberang yang bermuara di selatan kota. Luas wilayah kota Makassar seluruhnya berjumlah kurang lebih 175,77 Km2 daratan dan termasuk 11 pulau di selat Makassar ditambah luas wilayah perairan kurang lebih $100 \mathrm{Km}^{2}$. Jumlah kecamatan di kota Makassar sebanyak 14 kecamatan dan memiliki 143 kelurahan. Diantara kecamatan tersebut, ada tujuh kecamatan yang berbatasan dengan pantai yaitu kecamatan Tamalate, Mariso, Wajo, Ujung Tanah, Tallo, Tamalanrea dan Biringkanaya. Kota Makassar sendiri berdekatan dengan sejumlah kabupaten yakni sebelah utara dengan kabupaten Pangkep, sebelah timur dengan kabupaten Maros, sebelah selatan dengan kabupaten Gowa dan sebelah barat dengan Selat Makassar. Dari gambaran selintas mengenai lokasi dan kondisi geografis Makassar, memberi penjelasan bahwa secara geografis, kota Makassar memang sangat strategis dilihat dari sisi kepentingan ekonomi maupun politik. Dari sisi ekonomi, Makassar menjadi simpul jasa distribusi yang tentunya akan lebih efisien dibandingkan daerah lain. Memang selama ini kebijakan makro pemerintah yang seolah-olah menjadikan Surabaya sebagai home base pengelolaan produk-produk draft kawasan Timur Indonesia, membuat 
Makassar kurang dikembangkan secara optimal.

Usaha Pemerintah Kota Makassar dalam menangani permasalahan ekploitasi ekonomi terhadap anak tersebut merupakan implementasi dari Pasal 66 ayat 1 UU RI No. 23 Tahun 2002 tentang Perlindungan Anak yang menyatakan bahwa "Perlindungan khusus bagi anak yang dieksploitasi secara ekonomi dan/atau seksual sebagaimana dimaksud dalam pasal 59 merupakan kewajiban dan tanggungjawab pemerintah dan masyarakat". Dan dalam ayat 2 disebutkan bahwa "Perlindungan khusus bagi anak yang dieksploitasi sebagaimana dimaksud dalam ayat 1 dilakukan melalui: (a) Penyebarluasan dan/atau sosialisasi ketentuan perundang-undangan yang berkaitan dengan perlindungan anak yang dieksploitasi secara ekonomi dan/atau seksual; (b) Pemantauan, pelaporan, dan pemberian sanksi; (c) Pelibatan berbagai instansi pemerintah, perusahaan, serikat pekerja, lembaga swadaya masyarakat, dan masyarakat dalam penghapusan eksploitasi terhadap anak secara ekonomi dan/atau seksual". Perlu diketahui bahwa dalam Pasal 59 UU RI No. 23 Tahun 2002 dinyatakan bahwa "Pemerintah dan lembaga lainnya berkewajiban dan bertanggung jawab untuk memberikan perlindungan khusus, antara lain kepada anak yang tereksploitasi secara ekonomi dan/ atau seksual".

Hak anak adalah merupakan bagian dari hak asasi manusia yang wajib dijamin, dilindungi, dan dipenuhi oleh orang tua, keluarga, masyarakat, pemerintah, dan negara agar dapat hidup, tumbuh, berkembang, dan berpartisipasi, secara optimal sesuai dengan harkat dan martabat kemanusiaan, serta mendapat perlindungan dari kekerasan dan diskriminasi.

Menghormati dan menjamin hak anak berarti tidak ada perbedaan atas dasar apapun, termasuk atas dasar ras, warna kulit, jenis kelamin, bahasa, keyakinan dan lainnya baik pada diri sianak maupun pada orang tuanya. 
Program ini dimaksudkan agar setiap anak mendapatkan perlakuan yang sama oleh Negara.

Upaya menghormati dan menjamin hak bagi anak dapat di artikan sebagai upaya perlindungan hukum terhadap berbagai kebebasan dan hak asasi anak serta berbagai kepentingan yang berhubungan dengan kesejahteraan anak. Jadi masalah menghormati dan menjamin hak bagi anak mencakup ruang lingkup yang sangat luas. Ruang lingkup yang cukup luas dari masalah anak, terlihat dari cukup banyaknya dokumen/instrument internasional yang berkaitan dengan masalah anak ini yang diantarannya adalah masalah ekploitasi anak, oleh sebab itu upaya menghormati dan menjamin hak anak terhadap anak yang tereksploitasi ekonomi dilakukan dengan berdasarkan pasal 19 Kepres Nomor 36 tahun 1990 tentang Konvensi Hak-Hak Anak, yang isinya: (1) Negara-negara Pihak harus mengambil semua tindakan legislatif, administratif, sosial dan pendidikan yang tepat untuk melindungi anak dari semua bentuk kekerasan fisik atau mental, luka-luka atau penyalahgunaan, penelantaran atau perlakuan alpa, perlakuan buruk atau eksploitasi, termasuk penyalahgunaan seks selama dalam pengasuhan (para) orang tua, wali hukum atau orang lain manapun yang memiliki tanggung jawab mengasuh anak; (2) Tindakantindakan perlindungan tersebut, sebagai layaknya, seharusnya mencakup prosedur-prosedur yang efektif untuk penyusunan programprogram sosial untuk memberikan dukungan yang perlu bagi mereka yang mempunyai tanggung jawab perawatan anak, dan juga untuk bentuk-bentuk pencegahan lain, dan untuk identifikasi, melaporkan, penyerahan, pemeriksaan, perlakuan dan tindak lanjut kejadian- kejadian perlakuan buruk terhadap anak yagn digambarkan sebelum ini, dan, sebagaimana layaknya, untuk keterlibatan pengadilan".

Strategi yang dilakukan Pemerintah Dinas Sosial kota Makassar dalam hal menghormati dan 
menjamin hak anak ini sudah baik tetapi masih dalam konteks konsep belum pada tahap implementasinya sehingga masih belum dijalankan dengan semestinya.

Sarana dan prasarana merupakan perlengkapan daerah untuk tujuan melayani kebutuhan untuk masyarakat setempat. Pembangunan sarana dan prasarana di dinas sosial dalam melakukan perlindungan anak di bawah umur merupakan tujuan dinas sosial dalam membantu anak di bawah umur dalam bentuk sarana dan prasarananya. Yang dimana sarana merupakan sesuatu yang dapat digunakan sebagai angkat atau peralatan dalam mencapai maksud dan tujuan, sedangkan prasarana adalah sesuatu yang merupakan faktor penunjang terlaksananya suatu proses kegiatan yang dapat di klasifikasikan hal- hal yang termasuk sarana dan prasarana.

Sumber daya manusia / staf memiliki peranan penting dalam implementasi kebijakan. Karena bagaimanapun jelas dan konsistensinya ketentuan-ketentuan dan aturan-aturan serta bagaimanapun akuratnya penyampaian tersebut, jika para pelaksana kebijakan kurang menjalankan kewajiban mereka dan kurang mengandalkan keahlian dan kemampuan mereka secara efektif maka kebijakan tersebut tidak akan berjalan sebagaimana mestinya.

Orang tua merupakan sosok terpenting dan paling berjasa dalam sejarah kehidupan manusia. Kehadirannya sungguh tak ternilai harganya. Pengorbananya pun tidak terkira dan tidak terhingga besarnya. Semua waktu, tenaga dan harta ia korbankan hanya untuk memberikan kebahagian bagi sang buah hatinya. Pendidikan dan pembimbingan terhadap putra- putrinya pun selalu ia lakukan hanya agar putra- putrinya nanti mampu menjadi seorang yang sukses baik di dunia maupun di akhirat kelak.

Hak dan kewajiban orang tua dalam melindungi anak mereka masih minim, sebab masih banyak orang tua yang melantarkan anak mereka ke 
jalanan untuk bisa mencari uang sendiri untuk menghidupi kehidupannya. Dan juga dapat berpengaruh dengan pola pikir yang mereka miliki, sehingga anak yang memiliki potensi atau kelebihan dalam dirinya, dia tidak dapat mengkreasikan dirinya karena tegangan dari orang tua mereka yang acuh terhadap dirinya.

Kewajiban orang tua terhadap anaknya adalah sebuah wujud aktualitas hak- hak anak yang harus dipenuhi oleh orang tua karena kewajiban orang tua adalah hak dari seorang anak.Orang tua pun mempunyai hak dan kewajiban terhadap anaknya yang harus ditunaikan.

Anak adalah merupakan harta yang tak ternilai harganya, tidak saja dilihat dalam perspektif sosial, budaya, ekonomi, politik, hukum, tetapi juga dalam perspektif keberlanjutan sebuah generasi keluarga, suku, ras, maupun bangsa.Anak memiliki hak dalam menentukan hidup mereka. Yang dimana anak pada usia pra-sekolah atau sekarang lebih di kenal dengan anak anak usia dini yang berada pada rentang usia 0-6 tahun oleh para ahli dianggap sebagai usia emas dalam tahap perkembangan manusia. Perkembangan anak di usia ini menetukan perkembangan anak di masa- masa selanjutnya. Perkembangan intelektual, spriritual dan sosial emosional seseorang manusia merupakan hasil dari perkembangan di usia- usia dini seseorang. Oleh karena itu, pendidikan usia dini merupakan tonggak keberhasilan seseorang dalam menjalani pendidikan di tahapan selanjutnya yang mengatakan bahwa hak anak di usia dini memiliki kecerdasan yang membanggakan, dimana kecerdasan anak cepat menangkap sesuatu yang bisa melatih pola pikir mereka.

Anak di berikan potensi bawaan yaitu potensi indrawi (psikomotorik), IQ,EQ dan SQ, semua manusia perlu mensyukuri pembekalan dari Allah SWT, dengan mengaktualisasikannnya menjadi kompetensi. Melalui teori- teori 
tentang anak, maka pemahaman penyelenggara pendidikan anak usia dini terhadap konsep dan pelaksanaan pembelajaran akan lebih sesuai dengan karakteristik dan perkembangan psikologis anak. Seperti yang di ungkapkan anak yang mendapatkan perlakuan eksploitasi ekonomi.

$\begin{array}{ccc} & \text { Dalam era globalisasi yang } \\ \text { sangat } & \text { berpengaruh } & \text { pada }\end{array}$
pengembangan sumber daya manusia, maka disini dinas sosial akan mempersiapkan sejak dini mungkin menghadapi tantangan yang semakin berat khususnya perlindungan anak bagaimana fungsi dinas sosial mengenai perlindungannya dan dalam mengelola sumber daya manusia. Dengan adanya memotivasi dan mempengaruhi bawahanya untuk bertanggung jawab atas tugas yang diembannya atau diberikan agar tercapai suatu tujuan dengan menyelesaikan berbagai masalah yang ada pada sumber daya manusia atau karyawannya dan dalam meningkatkan SDM-nya yang berprodukrivitas, Untuk meningkatkan sumber daya manusia pada karyawanya maka dinas sosial itu harus memotivasi. Motivasi adalah membuat orang mengerjakan apa yang dikerjakan dengan rela dan baik.

Kualitas sumber daya manusia berkaitan dengan keterampilan, dedikasi, profesionalitas, dan kompetensi dibidangnya.Sedangkan kuantitas berkaitan dengan jumlah sumber daya manusia apakah sudah cukup untuk melengkapi seluruh kelompok sasaran. Sumber daya manusia sangat berpengaruh terhadap keberhasilan implementasi, sebab tanpa sumber daya manusia implementasi akan berjalan lambat.

$$
\text { Kurangnya kelengkapan }
$$

fasilitas di Dinas Sosial Kota Makassar dalam mengimplementasikan perlindungan anak di bawah umur sangat kurang, oleh karena itu banyak anak- anak di luar sana yang bekerja untuk menghidupi kehidupannya agar bisa bertahan hidup. Sarana ialah sesuatu yang dapat di gunakan sebagai angket atau peralatan dalam mencapai maksud dan tujuan, sedangkan 
prasarana adalah sesuatu yang merupakan faktor penunjang terlaksananya suatu proses kegiatan yang dapat di klarifikasikan hal- hal yang termasuk sarana dan prasarana.

Perlindungan anak di bawah umur di kota Makassar masih membutuhkan sarana dan prasarana yang membantu pemerintah agar perlindungan anak di bawah umur di kota Makassar lebih maksimal. Walaupun sarana dan prasarana yang ada di kota Makassar dalam perlindungan anak di bawah umur masih terbatas tetapi itu tidak mengurangu semangat pemerintah dalam menjaga serta melindungi anakanak di bawah umur.

Dana dalam perlindungan anak di bawah umur sangat penting. Setiap asrama atau tempat untuk menampung anak- anak di bawah umur sangatmembutuhkan dana yang besar untuk bisa membantu kehidupan mereka. Karena asrama harus di lengkapi dengan sarana dan prasarana agar anak- anak tersebut bisa nyaman tinggal di tempat tersebut serta bisa mengembangkan potensi atau bakat yang mereka punya.Usia anak di bawah umur harus dilindungi dan di jaga dari orang- orang yang berniat jahat kepada mereka.

Apabila pemerintah Kota Makassar dalam hal ini Dinas Sosial hanya mengandalkan APBD dalam perlindungan anak di bawah umur di Kota Makassar itu sangat sulit dalam pelaksanaannya.Perlindungan anak di bawah umur menggunakan banyak sarana dan prasarana agar mereka bisa merasa nyaman berada di tempat yang asing bagi mereka.

\section{KESIMPULAN}

Berdasarkan hasil penelitian mengenai implementasi kebijakan perlindungan Pekerja di bawah umur di Dinas sosial Kota Makassar dapat disimpulkan sebagai berikut: (1) Implementasi Kebijakan Perlindungan Pekerja di Bawah Umur di Dinas Sosial Kota Makassar Atas Kegiatan Ekploitasi Ekonomi. Diantaranya yaitu Menghormati dan Menjamin Hak Anak Cukup optimal, terlihat dari 
aparat memberi pelayanan tempat tinggal serta sarana dan prasana agar mereka bisa mengembangkan potensi atau kemampuan yang mereka miliki serta bisa terhindar dari orang yang berniat untuk memperkerjakan mereka. hak dan kewajiban orang tua dalam melakukan perlindungan anak di bawah umur, cukup optimal; (2) Faktor pendukung terhadap implementasi perlindungan pekerja di bawah umur di Dinas Sosial di Kota Makassar terdiri dari kualitas Sumber daya Manusia yang dimana sumber daya manusia ini sangat di perlukan dalam perlindungan anak di bawah umur dalam memotivasikan mereka, faktor penghambat dalam implementasikan kebijakan dalam perlindungan pekerja di bawah umur di Dinas Sosial di Kota Makassar yakni, kurangya sarana dan prasarana dapat mengakibatkan kendala bagi anak dibawah umur, karena fasilitas yang di sediakan tidak sesuai dengan apa yang dijanjikan oleh mereka, seharusnya pemerintah bisa mengambil solusi dengan cepat, agar anak- anak merasa di lindungi serta di jaga. Keterbatasan dana membuat mereka rela turun ke jalan untuk bisa menghidupi kehidupan mereka.

\section{DAFTAR PUSTAKA}

Haryadi, Dedi, Tjandraningsih dan Indrasari, 1995. Buruh Anak dan Dinamika Indsustri Kecil. Alkatiga, Bandung.

Gultom, Maidin, (2012), Perlindungan Hukum Terhadap Anak Dan Perempuan, Bandung, Refika Aditama.

Wiryani, Fisik. 2003, Perlindungan Pekerja Anak, Pusat Studi Kajian Wanita, UMM Press, Malang.

Purwanto, Erwan Agus dan Dyah Ratih Sulistyastuti,2012, Implementasi Kebijakan Publik (Konsep dan Aplikasinya di Indonesia), Gava Media Yogyakarta.

Winarno, Budi, (2012), Kebijakan Publik (Teori Proses dan Studi Kasus), Yogyakarta, CAPS.

Mustari, Nuryanti.(2013), Implementasi Kebijakan Publik, Makassar, Membumi, Publishing.

Agustin, Leo, (2008), Dasar-dasar Kebijakan Publik, Bandung, Alfabeta. 
Luankali Bernadus, (2007), Analisis

Kebijakan Publik dalam

Pengambilan Keputusan,

Jakarta, AMELIA Press.

Parsons, Wayne, (2006), Public

Policy; Pengantar Teori \&

Praktik Analis Kebijakan,

Jakarta, Kencana.

Martini, 2002. Analisa Suatu Sistem Peradilan Anak, FISIP UI, Jakarta. 